\title{
BULLFROG HEMOGRAM UNDER MANAGEMENT STRESS
}

\author{
Hemograma de rã-touro sob estresse de manejo
}

\author{
Patrícia Coelho Teixeira ${ }^{1}$, Irene Bastos Franceschini Vicentini ${ }^{2}$, Claudia Maris Ferreira ${ }^{3}$, \\ Fernanda Menezes França ${ }^{4}$, Isabela Cristina Antunes da Costa Bordon ${ }^{5}$, \\ Maria José Tavares Ranzani-Paiva ${ }^{3}$
}

\begin{abstract}
Stress is one of the major obstacles in frog culture and can be caused by factors such as inappropriate farming systems; inadequate management among other situations. The objective of the present study was to assess the hemogram, erythrogram and leukogram of bullfrogs (L. catesbeianus) when exposed to stress caused by different types of management: density and handling (manipulation), developed in the laboratory and repeated in the field for the appropriate comparisons in a experimental period of 30 days. The density experiment was conducted with four treatments: 70 animals $\mathrm{m}^{-2}$ (D70); 100 animals $\mathrm{m}^{-2}$ (D100), Control; 150 animals $\mathrm{m}^{-2}$ (D150) and 200 animals $\mathrm{m}^{-2}$ (D200), with 10, 14, 21 and 28 animals/box in the laboratory, respectively. Each treatment was performed with three simultaneous replicates. The handling experiment was conducted with three treatments: Treatment Without Handling (WH); Treatment with Partial Handling (PH) every 15 days and Treatment with Total Handling (TH) every 15 days. Each treatment was performed with four simultaneous replications. The methodology of the blood analysis followed international recommendations. In the present study we could observe that the animals of the field experiment did not reflect the same stress response observed in the laboratory in both experiment, which demonstrated the plasticity of these animals.
\end{abstract}

Index terms: L. catesbeianus; density; handling; physiological response; hematology.

\section{RESUMO}

O estresse é um dos maiores obstáculos na criação de rãs e pode ser causado por fatores como sistemas de criação inapropriados; manejos inadequados bem como outras situações. O objetivo do presente estudo foi avaliar o hemograma, eritrograma e o leucograma da rã-touro (L. catesbeianus) quando expostas ao estresse de diferentes manejos: adensamento e manipulação desenvolvidos no laboratório e repetidos no campo para as devidas comparações em um período experimental de 30 dias. $\mathrm{O}$ experimento de densidade foi conduzido com quatro tratamentos: 70 animais $\mathrm{m}^{-2}$ (D70); 100 animais $\mathrm{m}^{-2}$ (D100), Controle; 150 animais $\mathrm{m}^{-2}$ (D150) e 200 animais $\mathrm{m}^{-2}$ (D200) com respectivos 10, 14, 21 e 28 animais/caixa no laboratório. Cada tratamento foi realizado com três réplicas simultâneas. O experimento de triagem foi conduzido com três tratamentos: Tratamento Sem Triagem (ST); Tratamento com Triagem Parcial (TP) a cada 15 dias e Tratamento com Triagem Total (TT) a cada 15 dias. Cada tratamento foi realizado com quatro réplicas simultâneas. A metodologia das análises de sangue seguiu as recomendações internacionais. No presente estudo pode-se observar que os animais experimentados em campo não refletiram a mesma resposta de estresse observada no laboratório nos dois experimentos, o que conferiu a plasticidade destes animais.

Termos para indexação: L. catesbeianus; densidade; manejo; resposta fisiológica; hematologia.

\section{INTRODUCTION}

Density is an extremely important factor for the quality of amphibians, Loman (2004), but it acts as a chronic stressor that may change the homeostasis of the animal (Hayes, 1997; Glennemeier; Denver, 2002; RotNikcevic; Denver; Wassersug, 2005).

The handling, separation of animals according to their size to standardize the group contributes to animal welfare (Fontanello et al., 1993; Ferreira; Pimenta; Paiva-Neto, 2002), but it acts as an acute stressor and may as well change the homeostasis of them (Langkilde; Shine, 2006).

The hematological parameters represent an alternative method for the analysis of the effects of stress that cause quantitative and qualitative changes in the blood components (Wright, 2001; Allender; Fry, 2008). According to Rocha et al. (2010) and Teixeira et al. (2012), inadequate management act as a source of stress and can contribute to alterations in hemogram in Rana catesbeiana animals.

\footnotetext{
${ }^{1}$ Agência Paulista de Tecnologia dos Agronegócios/APTA/SP - Instituto de Pesca/IP - Av. Francisco Matarazzo - 455 - Parque da Água Branca 05001-900 - São Paulo - SP - Brasil - pa_co75@yahoo.com.br

2Universidade Estadual Paulista Júlio de Mesquita Filho - UNESP - Bauru - SP - Brasil

${ }^{3}$ Agência Paulista de Tecnologia dos Agronegócios/APTA/SP - Instituto de Pesca/IP - São Paulo - SP - Brasil

${ }^{4}$ Universidade de São Paulo/USP - Lorena - SP - Brasil

5Universidade de São Paulo/USP - São Paulo - SP - Brasil

Received in july 25, 2014 and approved in december 3, 2014
}

Ciênc. Agrotec., Lavras, v.39, n.2, p.154-163, mar./abr., 2015 
The hypothesis is that the density and handling alter the hematological parameters so the objective of the present study was to assess the hemogram, erythrogram and leukogram of bullfrogs (Lithobates catesbeianus) subjected to stress caused by these different types of management.

\section{MATERIAL AND METHODS}

In the density experiment at the laboratory, 219 animals were used and placed initially in 40L propylene acclimation boxes $(0.33 \times 0.46 \times 0.27 \mathrm{~m})$ for four days, and then they were measured and randomly distributed in propylene experimental boxes $(0.47 \times 0.30 \times 0.17 \mathrm{~m})$, which contained water only on the side of the pool. In the field, 1,560 animals were used, stocked initially in 140L propylene acclimation boxes $(0.52 \times 0.69 \times 0.40 \mathrm{~m})$ for the same period, and then put in brickwork experimental boxes $(1.10 \times 0.77 \times 0.80 \mathrm{~m})$, slightly inclined so as to simulate a pool. In the handling experiment at the laboratory, 168 animals were used, stocked initially in the same $40 \mathrm{~L}$ propylene acclimation boxes and then in the propylene experimental boxes. In the field, 1,200 animals were used, placed initially in the same $40 \mathrm{~L}$ propylene acclimation boxes and then in the brickwork experimental boxes.

The animals were fed extruded feed containing $40 \%$ crude protein, in an amount of $10 \% \mathrm{LW}$ (live weight), once a day offered in trays, using fly larvae (Musca domestica) as a biological inducer. The water where the animals were kept in the laboratory was previously dechlorinated and changed daily very quickly, to disturb the animals as little as possible. In the field, the water of the farm reservoir was filtered by a system of stones and gravel in order to remove suspended solids. The change was performed by a system of elbows, with a continuous-flow water renewal. The photoperiod was 12:12, controlled by a timer and the mean air temperature was measured with a maximum and minimum thermometer. The mortality of the animals was recorded daily.

Blood samples were collected from the hindlimb vessel by puncture, with disposable and heparinized syringes and needles. Lidocaine at the concentration of...was used as local external anesthetic. The following analyses were performed: number of erythrocytes (RBC), counted in a Neubauer chamber using Hayem's solution as diluent; hematocrit $(\mathrm{Ht})$, using the microhematocrit method; hemoglobin rate $(\mathrm{Hb})$, using the cyanometahemoglobin method; Total Leukocyte Count (TLC) and Differential Leukocyte Count (DLC), in blood smears stained by MayGrünwald-Giemsa; and the absolute hematimetric indices were calculated: Mean Corpuscular Volume (MCV), Mean Corpuscular Hemoglobin (MCH) and Mean Corpuscular Hemoglobin Concentration (MCHC).

\section{Experiment of stress caused by density}

Postmetamorphic bullfrog froglets ( $L$. catesbeianus) with mean weight of $13.83 \pm 3.37 \mathrm{~g}$ were used in four treatments: 70 animals $\mathrm{m}^{-2}$ (D70); 100 animals $\mathrm{m}^{-2}$ (D100), (Control); 150 animals. $\mathrm{m}^{-2}$ (D150) and 200 animals $\mathrm{m}^{-2}$ (D200), representing 10, 14, 21 and 28 animals/box in the laboratory, respectively. Each treatment was performed with three simultaneous replications during an experimental period of 30 days. As the animals were removed for sampling, the internal space of the boxes was readjusted with a plastic fiber apparatus simulating a wall that was moved towards the pool so that the initial density was kept.

In the laboratory, two specimens from each replication (6 animals/treatment) were sampled on the $15^{\text {th }}$ and the $30^{\text {th }}$ day of experiment, totalizing 48 animals. In the field, three specimens from each replication (9 animals/treatment) were sampled at different collection times, totalizing 72 animals.

\section{Experiment of stress caused by handling}

Bullfrog froglets (L. catesbeianus) with mean weight of $10.78 \pm 1.82 \mathrm{~g}$ were used in three treatments: Treatment Without Handling (WH); Treatment with Partial Handling (PH) every 15 days and Treatment with Total Handling (TH) every 15 days. Each treatment was performed with four simultaneous replications during an experimental period of 30 days.

The treatment Without Handling (WH) was characterized by a process without manipulation. The treatment with Partial Handling $(\mathrm{PH})$ consisted of the partial removal of the animals taking their size into account. In other words, the animals that were much larger or much smaller than the other ones from the same batch (around $10 \%$ of the animals) were removed and placed in buckets, 1 bucket/replication. Those animals were rearranged by size and put back into the boxes in order to keep the density. The treatment with Total Handling (TH) consisted of the total removal of the animals from the boxes and separation according to their size: small ( $\mathrm{S}, 8 \mathrm{~g})$, medium small (Ms, $10 \mathrm{~g})$, medium large $(\mathrm{Ml}, 12 \mathrm{~g})$ and large $(\mathrm{L}, 14 \mathrm{~g})$ in different buckets, 4 buckets/replication. Those animals were rearranged by size the same way and put back into the boxes keeping the density. 
Both in the laboratory and in the field, three specimens from each replication ( 9 animals/treatment) were sampled on the $15^{\text {th }}$ and the $30^{\text {th }}$ day of experiment, totalizing 72 animals. The density used was 100 animals per square meter, corresponding to 14 animals/box in the laboratory.

\section{Statistical analysis}

Tests were performed to verify the normality of data (Shapiro-Wilk and Bartlett) and the homogeneity of variances $(\mathrm{F})$. The data of white cells were transformed into root $(\mathrm{x}+1)$, so as to meet those assumptions. The blood data were tested by the analysis of variance (ANOVA TWO WAY), followed by an a posteriori Tukey test in order to verify in what situations there were significant differences in the number of cells with regard to density and handling. The differences were considered as significant when $\mathrm{p} \leq 0.05$ (Zar, 1999). The statistical software used was STATISTICA (Statsoft).

\section{RESULTS AND DISCUSSION}

\section{Experiment of stress caused by density}

The density of 100 animals per square meter (frogs up to $30 \mathrm{~g}$ ) is recommended for froglets with regard to growth and survival in terms of cost-benefit in commercial production in a semi-dry system (Ferreira; Pimenta; PaivaNeto, 2002). According to Fontanello et al. (1993), animal size uniformity is represented by the combination between weight and length of the animal.

On the $15^{\text {th }}$ day, the animals were at the beginning of their growth, a stage where they are learning to eat, and due to their uniformity, the confrontations at this stage were considered light. On the 30th day, the animals were growing exponentially, with some of them developing faster than the others (i.e. nonuniformity), which in addition to the high voracity, made the confrontations more intense.

The animals in the beginning of the experiment showed number of erythrocytes: $351,000.00 \pm 9,669.54$ $10^{4} \mathrm{~mm}^{-3}$; and the mean corpuscular volume:821.72 \pm 9.91 fL. The erythrogram (Table 1), in the laboratory, on the $15^{\text {th }}$ day, presented an increase in the number of erythrocytes and the mean corpuscular volume remained constant in the animals subjected to D200. On the other hand, a decrease in the number of erythrocytes was observed on the $30^{\text {th }}$ day, but with increase in mean corpuscular volume, which suggested that throughout the experiment "young" red blood cells with larger volume were recruited to the blood system to give the necessary oxygen supply during the confrontations. The same way Teixeira et al. (2012) observed an increase in MCV in chronic stress with the same species. In field, on the $15^{\text {th }}$ and $30^{\text {th }}$ days, an increase in the number of erythrocytes was observed in the animals subjected to D200, but with decrease in the mean corpuscular volume, which suggested the presence of "mature" red blood cells with lower volume, a sign of no stress condition.

The animals in the beginning of experiment showed $4,443.00 \pm 151.95$ leukocyte total $\mathrm{mm}^{-3} ; 3,461.71 \pm 104.17$ lymphocytes $\mathrm{mm}^{-3} ; 120.51 \pm 12.51$ neutrophils $\mathrm{mm}^{-3}$; $759.17 \pm 105.72$ basophils $\mathrm{mm}^{-3} ; 4.24 \pm 8.97$ eosinophil $\mathrm{mm}^{-3} ; 11.65 \pm 8.29$ monocytes $\mathrm{mm}^{-3}$. The leukogram (Table 2), in the laboratory, on the $15^{\text {th }}$ day, presented small changes in almost all the leukocytes and a more expressive decrease in the monocytes in the animals subjected to D200. According to Martin et al. (2005) and Kiank et al. (2006), chronic stressors usually suppress the immune system changing the number of leukocytes. On the $30^{\text {th }}$ day, a decrease in leukocytes and lymphocytes and increase in neutrophils, basophils and monocytes were observed, and the eosinophilic alteration was more expressive. High density may change the leukocyte profile, where increase stress presented changes in the population of circulating leukocytes, specifically with reduction in lymphocytes and increase in neutrophils in salamanders reared at high densities (Davis; Maerz, 2009).

In field, on the $15^{\text {th }}$ day, a decrease in the number of total leukocytes, lymphocytes and neutrophils and increase in the other leukocytes were observed in the animals subjected to D200. On the other hand, an increase in the number of total leukocytes, lymphocytes and neutrophils, and decrease in the other cells were observed, on the $30^{\text {th }}$ day, which suggested possible inflammation front of the signs of cannibalism in the smaller animals whose presents the head whitening, also known as "white head". Davis (2009) reported that after stress condition the neutrophils, eosinophils and monocytes became more abundant, which means in this case understood as an inflammatory process.

\section{Experiment of stress caused by handling}

On the $15^{\text {th }}$ day, the animals were growing exponentially, which in addition to the high voracity, made the confrontations more intense. However, on the $30^{\text {th }}$ day the animals were more used and conditioned to that situation, and due to their "uniformity" (Fontanello et al., 1993) the confrontations were lighter. 


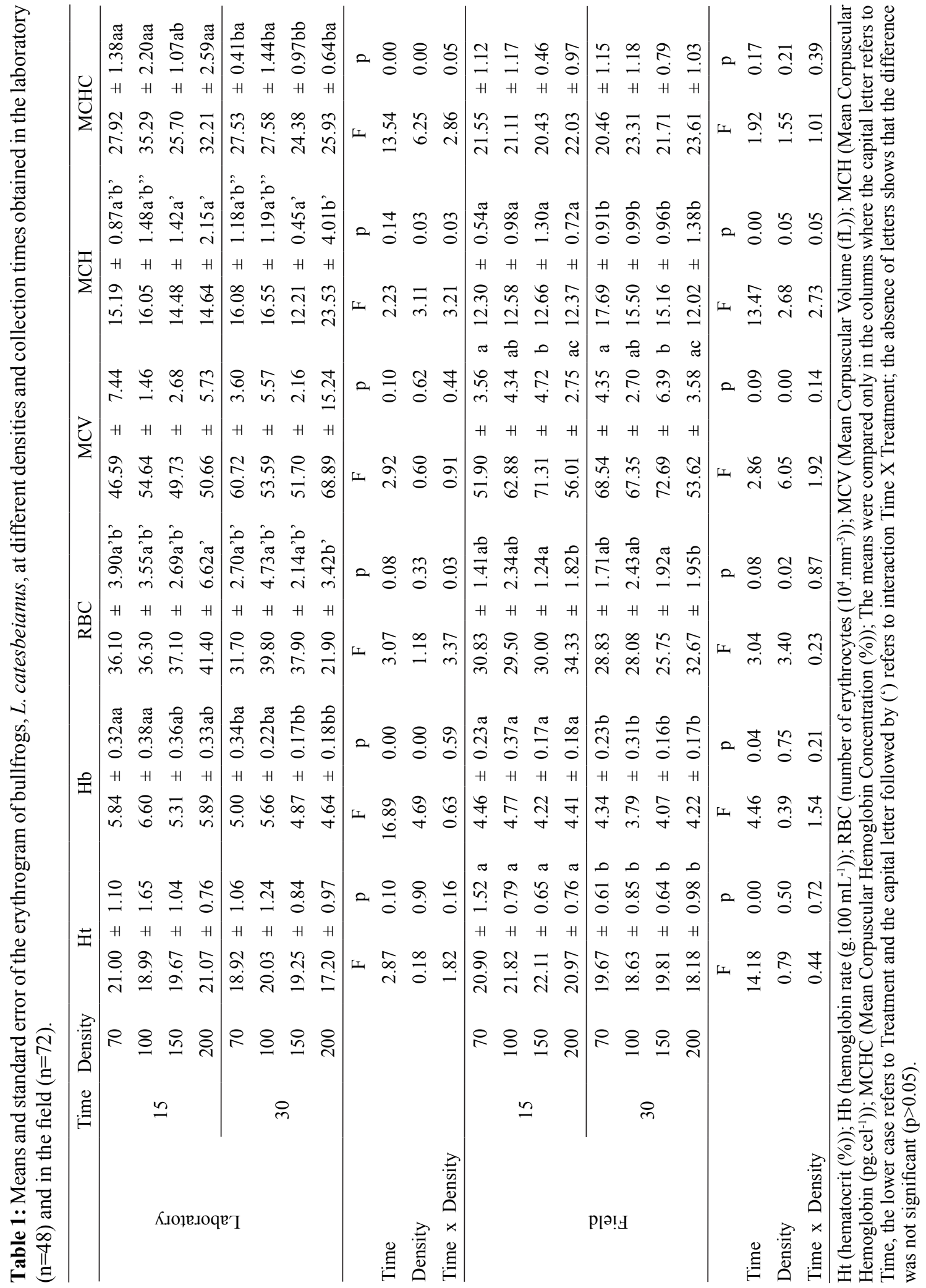




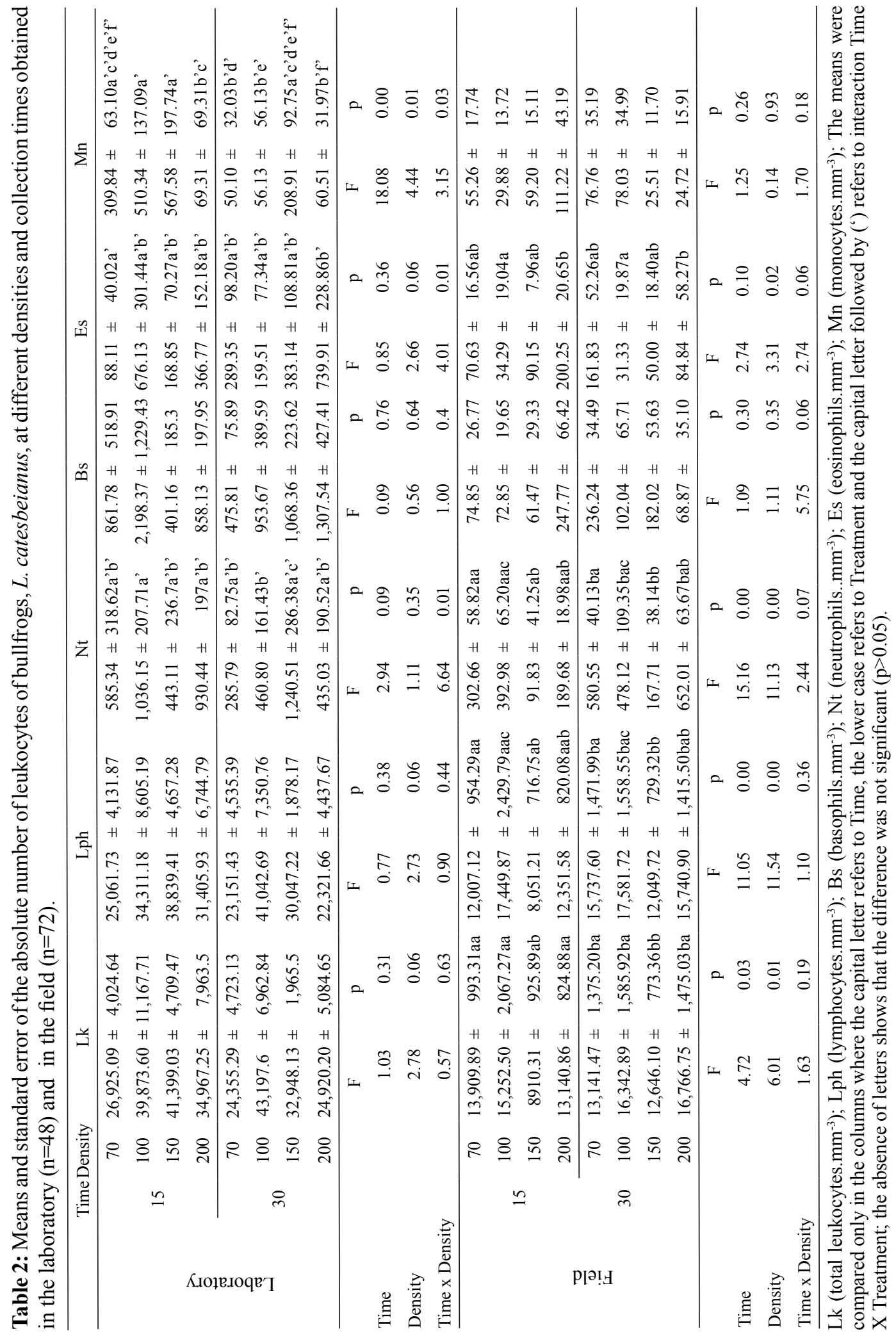


The animals in the beginning of the experiment showed number of erythrocytes: $362,777 .+78 \pm 15,945.02$ $10^{4} \mathrm{~mm}^{-3}$; mean corpuscular volume: $412.88 \pm 28.58 \mathrm{fL}$. The erythrogram (Table 3 ), in the laboratory, on the $15^{\text {th }}$ day, presented an increase in the number of erythrocytes and decrease in the mean corpuscular volume in the animals subjected to TH. The same way Rocha et al. (2010) observed an increase in the number of erythrocytes in acute stress with the same species. On the other hand, a decrease in the number of erythrocytes was observed, but the mean corpuscular volume remained constant on the $30^{\text {th }}$ day.

In the field, on the $15^{\text {th }}$ day, a decrease in the number of erythrocytes and the mean corpuscular volume were observed in the animals subjected to $\mathrm{TH}$, and on the $30^{\text {th }}$ day, decrease in the number of erythrocytes was observed, but the mean corpuscular volume remained constant.

It is important to point out here that the hematological approach for estimating stress is not as time-sensitive as direct hormonal sampling (Davis et al., 2008), where animals must be sampled within minutes of capture (Romero; Reed, 2005; Romero; Romero, 2002). In fact, in amphibians the time for the hematological effect of stress occurs on the order of hours to days (Bennett et al., 1972), which means that any potential effects of capture, handling, or transport are minimal if blood is obtained the "same" day of capture. The stress stimulus in the present experiment of handling was applied on the day before the collection, so there was not enough time for the blood cells to respond.

The animals in the beginning of experiment showed $14,417.41 \pm 849.64$ leukocytes total $\mathrm{mm}^{-3}$; $12,459.42 \pm 714.53$ lymphocytes $\mathrm{mm}^{-3} ; 549.78 \pm 46.46$ neutrophils $\mathrm{mm}^{-3} ; 237.99 \pm 66.66$ basophils $\mathrm{mm}^{-}$ ${ }^{3} ; 120.44 \pm 34.76$ eosinophils $\mathrm{mm}^{-3} ; 139.69 \pm 42.26$ monocytes $\mathrm{mm}^{-3}$. The leukogram (Table 4), in the laboratory, on the $15^{\text {th }}$ and $30^{\text {th }}$ days, presented a decrease in the number of leukocytes, lymphocytes, neutrophils, basophils, eosinophils and monocytes in the animals subjected to TH. Similar results were observed where acute stress caused decrease in the number of circulating lymphocytes (Maule; Vanderkooi, 1999).

In field, on the $15^{\text {th }}$ day, a decrease in the number of leukocytes, lymphocytes, basophils and eosinophils, and increase in the number of neutrophils and monocytes were observed in the animals subjected to TH. On the $30^{\text {th }}$ day, however, the animals exhibited an increase in the number of leukocytes, lymphocytes, basophils, neutrophils and monocytes, and decrease in the number of eosinophils were observed, which suggested possible inflammation front of the signs of cannibalism, even reduced by the manipulation. Increase in the number of neutrophils and decrease in the number of eosinophils were observed in $R$. pipiens exposed to the cold (Maniero; Carey, 1997), and in salamanders exposed to capture/"handling" (Davis; Maerzs, 2010) and in a challenge of $R$. catesbeiana with chytridio (Davis et al., 2010). A decrease in the number of eosinophils were verified in trematode infection by Kiesecker (2002), Belden and Kiesecker (2005), Rohr, Schotthoefer and Raffel (2008).

The nonuniformity of size in the animals from the highest densities was observed during the density experiment in the laboratory, showing a situation of territoriality between the largest animals and the smallest ones. However, there was neither mortality nor signs of cannibalism in the different treatments. In the field, the nonuniformity was generalized for all the treatments similarly, regardless of density, with signs of cannibalism and mortality. According to Cohen and Alford (1993) and Altwegg (2003), high density may cause reduction in the growth of the animal. On the other hand, in the handling experiment in the laboratory, uniformity of size was observed in the different treatments, which contributed to the absence of signs of cannibalism and mortality in the animals. Nevertheless, the nonuniformity was generalized in the field, even when the respective manipulation was performed, which contributed to the appearance of signs of cannibalism and mortality on the $15^{\text {th }}$ and $30^{\text {th }}$ days. 


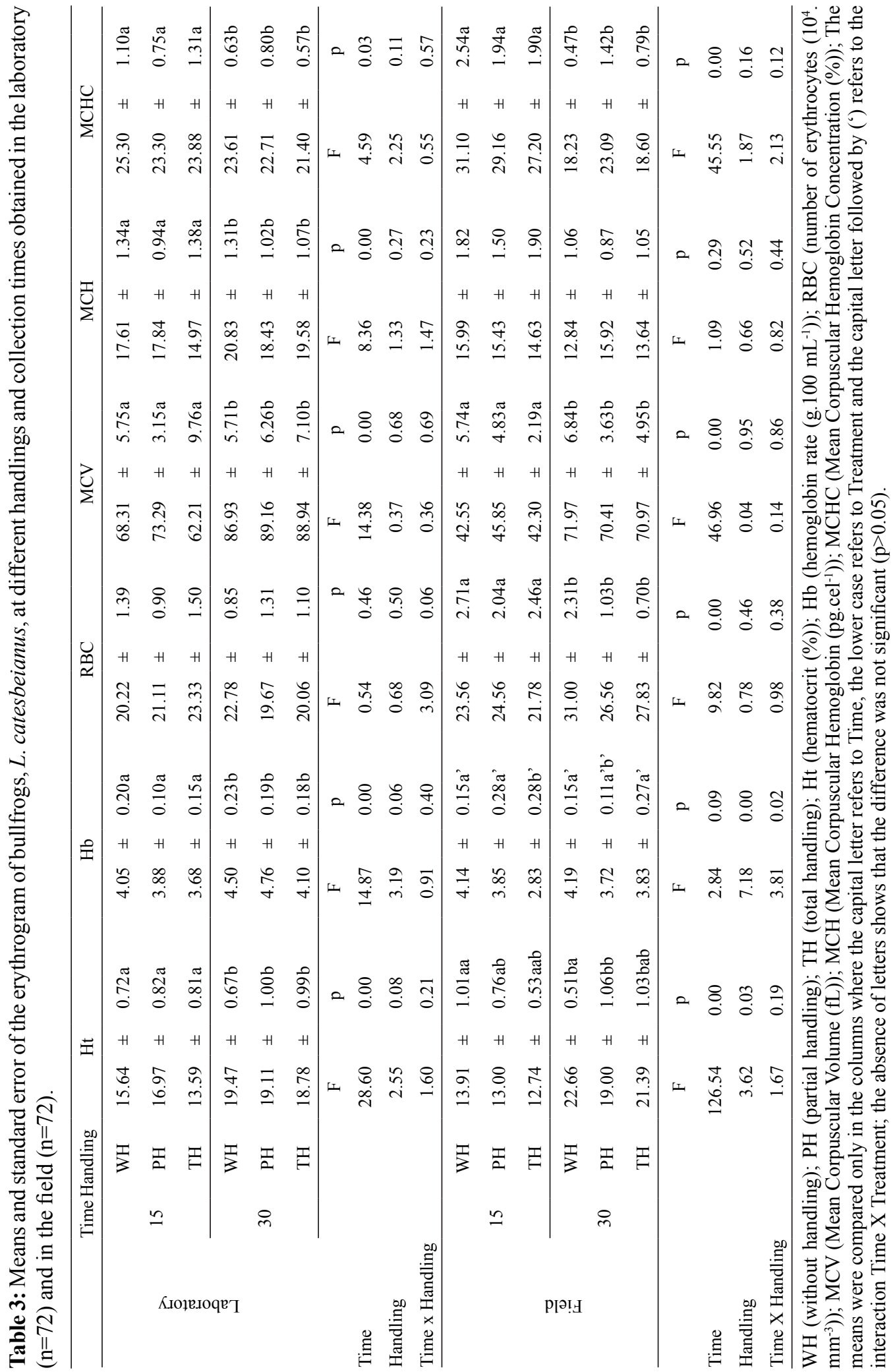




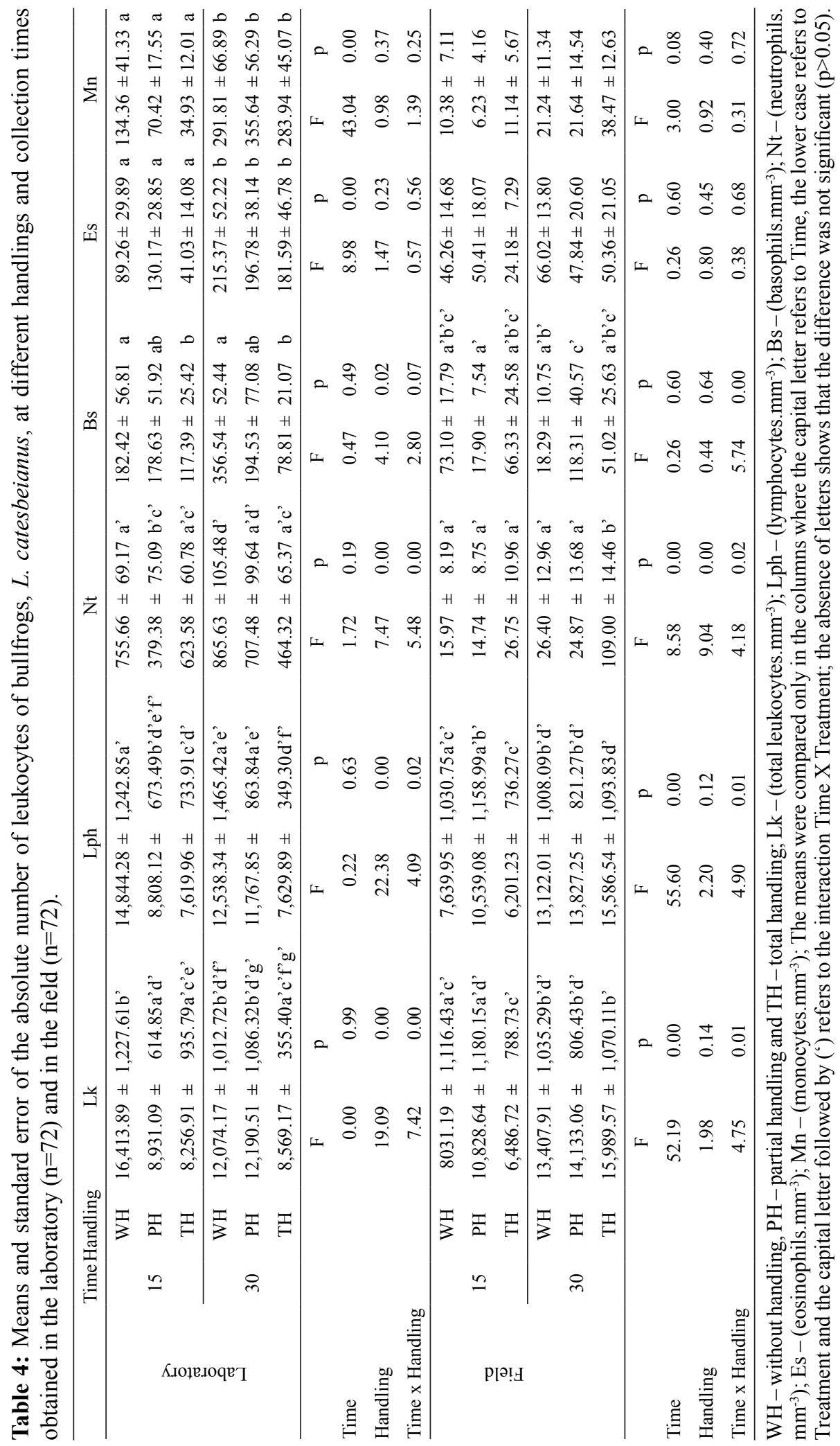

Ciênc. Agrotec., Lavras, v.39, n.2, p.154-163, mar./abr., 2015 


\section{CONCLUSIONS}

In the present study it was possible to observe that the animals of the field experiment did not reflect the same stress response verified in the laboratory. Under stressful situations, animals use different combinations of defense responses to maintain homeostasis, which not only increase or decrease in the immune response occurs, but also redistribution of immune cells all over the body. Furthermore, the bullfrogs exhibit excellent capacity to adapt to the different climate regimes, as well as to the different types of management if compared to other aquatic organisms, which demonstrates the plasticity of these animals.

\section{REFERENCES}

ALLENDER, M.C.; FRY, M.M. Amphibian hematology. Veterinary Clinical Exotic Animal. 11:463-480, 2008.

ALTWEGG, R. Multistage density dependence in an amphibian. Oecologia. 136:46-50, 2003.

BELDEN, L.K.; KIESECKER, J.M.

Glucocorticosteroid hormone treatment of larval treefrogs increases infection by Alaria sp trematode cercariae. Journal of Parasitology. 91:686-688, 2005.

BENNETT, M.F. et al. Changes in the blood of newts, Notophthalmus viridescens, following administration of hydrocortisone. Journal of Comparative Physiology. 80A:233-237, 1972.

COHEN, M.P.; ALFORD, R.A. Growth, survival and activity patterns of recently metamorphosed Bufo marinus. Wild Res. 20:1-13, 1993.

DAVIS, A.K. et al. The use of leukocyte profiles to measure stress in vertebrates: a review for ecologists. Functional Ecology. 22:760-772, 2008.

DAVIS, A.K. Metamorphosis-related changes in leukocyte profiles of larval bullfrogs (Rana catesbeiana). Comparative Clinical Pathology. 18:181-186, 2009.

DAVIS, A.K.; MAERZ, J.C. Effects of larval density on hematological stress indices in salamanders.

Journal of Experimental Zoology. 311(9):697-704, 2009.
DAVIS, A.K.; MAERZ, J.C. Effects of exogenous corticosterone on circulating leukocytes of a salamander (Ambystoma talpoideum) with unusually abundant eosinophils. International Journal of Zoology. 10:8, 2010.

DAVIS, A.K. et al. Effects of chytridiomycosis on circulating white blood cell distributions of bullfrog larvae (Rana catesbeiana). Comparative Clinical Pathology. 19(1):49-55, 2010.

FERREIRA, C.M.; PIMENTA, A.G.C.; PAIVA-NETO, J.S. Introdução à Ranicultura. Boletim Técnico do Instituto de Pesca. 33:1-15, 2002.

FONTANELLO, D. et al. Comparação de quatro sistemas de engorda de rã-touro (Rana catesbeiana, Shaw, 1802): Tanque-ilha, confinamento, anfigranja e gaiolas. 1-Desenvolvimento ponderal; 2-Custo operacional. Boletim do Instituto de Pesca. 20:1-16, 1993.

GLENNEMEIER, K.A.; DENVER, R.J. Role for corticoids in mediating the response of Rana pipiens tadpoles to intraspecific competition. Journal of Experimental Zoology. 292:32-40, 2002.

HAYES, T.B. Hormonal mechanisms as potential constraints on evolution: Examples from the Anura. American Zoologist. 37:482-490, 1997.

KIANK, C. et al. Stress susceptibility predicts the severity of immune depression and the failure to combat bacterial infections in chronically stressed mice. Brain, Behavior and Immunity. 20:359-368, 2006.

KIESECKER, J.M. Synergism between trematode infection and pesticide exposure: a link to amphibian deformities in nature? Proceedings of the National Academy of Sciences. 99:9900-9904, 2002.

LANGKILDE, T.; SHINE, R. How much stress do researchers inflict on their study animals? A case study using a scincid lizard, Eulamprus heatwolei. Journal of Expimental Biology. 209:1035-1043, 2006.

LOMAN, J. Density regulation in tadpoles of Rana temporaria: a full pond field experiment. Ecology. 85:1611-1618, 2004. 
MANIERO, G.D.; CAREY, C. Changes in selected aspects of immune function in the leopard frog, Rana pipiens, associated with exposure to cold. Journal of Comparative Physiology. 167B:256263, 1997.

MARTIN, L.B. et al. Corticosterone suppresses cutaneous immune function in temperate but not tropical house sparrows, Passer domesticus.

Geneneral and Comparative Endocrinology. 140:126-135, 2005.

MAULE, A.G.; VANDERKOOI, S.P. Stress-induced immune-endocrine interaction. In: BALM, P.H.M. (ed), Stress Physiology in Animals. Sheffield, UK: Sheffield Academic Press. 1999. p.205-245.

ROCHA, G.C. et al. Physiological response of American bullfrog tadpoles to stressor conditions of capture and hypoxia. Pesquisa Veterinária Brasileira. 30:891-896, 2010.

ROHR, J.R.; SCHOTTHOEFER, A.M.; RAFFEL, T.R. Agrochemicals increase trematode infections in a declining amphibian species. Nature. 455(7217):12351239, 2008.
ROMERO L.M.; REED J.M. Collecting baseline corticosterone samples in the field: is under $3 \mathrm{~min}$ good enough? Comparative Biochemistry Physiology A Molecular Integrative Physiology. 140:73-79, 2005.

ROMERO L.M.; ROMERO R.C. Corticosterone responses in wild birds: The importance of rapid initial sampling. Condor. 104:129-135, 2002.

ROT-NIKCEVIC, I.; DENVER, R.J.; WASSERSUG, R.J. The influence of visual and tactile stimulation on growth and metamorphosis in anuran larvae. Functional Ecology. 19:1008-1016, 2005.

TEIXEIRA, P.C. et al. Profile of cortisol, glycaemia, and blood parameters of American Bullfrog tadpoles Lithobates catesbeianus exposed to density and hypoxia stressors. Pesquisa Veterinária Brasileira. 32(Supl.1):91-98, 2012.

WRIGHT, K.M. Amphibian hematology. In: WRIGHT, K.M.; Whitaker, B.R. (eds). Amphibian Medicine and Captive Husbandry. Malabar FL: Krieger. 2001. p.111-122.

ZAR, J.H. Biostatical Analysis. New Jersey: Pretice Hall. 1999. 718p. 